\title{
Recombinant factor Vlla for uncontrollable bleeding in patients with extracorporeal membrane oxygenation: report on 15 cases and literature review
}

Xavier Repessé 1,3 $^{1,}$ Siu Ming Au ${ }^{1,3}$, Nicolas Bréchot ${ }^{1,3}$, Jean-Louis Trouillet ${ }^{1,3}$, Pascal Leprince ${ }^{2,3}$, Jean Chastre ${ }^{1,3}$, Alain Combes ${ }^{1,3}$ and Charles-Edouard Luyt ${ }^{1,3^{*}}$

\begin{abstract}
Introduction: Bleeding is the most frequent complication in patients receiving venoarterial or venovenous extracorporeal membrane oxygenation (ECMO). Recombinant activated factor VII ( $\mathrm{FVVIla)} \mathrm{has} \mathrm{been} \mathrm{used} \mathrm{in} \mathrm{these}$ patients with conflicting results. We describe our experience with rFVIla for refractory bleeding in this setting and review the cases reported in the literature.

Methods: Clinical characteristics, demographics, bleeding, thrombotic complications, mortality, and rFVIla administration were retrospectively collected for analysis from the electronic charts of the 15 patients in our intensive care unit who received rFVlla while being given ECMO from January 2006 to March 2011.

Results: Fifteen patients received rFVlla for persistent bleeding under venoarterial $(n=11)$ or venovenous $(n=4)$ ECMO. Bleeding dramatically decreased in 14 patients, without a major thrombotic event, except in one patient in whom a major stroke could not be ruled out. Two circuits were changed within the 48 hours after rFVIla administration for clots in the membrane and decreased oxygenation but without massive clotting. The mortality rate was $60 \%$.

Conclusions: rFVIla use for intractable hemorrhaging in patients receiving ECMO controlled bleeding, without major thrombotic events, and with 60\% dying. Hence, its use warrants discussion, and clinicians should be aware of the possibility of potentially life-threatening systemic thrombosis, emboli, or circuit clotting. Whether rFVIla can save the lives of such patients remains to be determined.
\end{abstract}

\section{Introduction}

Extracorporeal membrane oxygenation (ECMO) may be used successfully in patients with refractory life-threatening cardiac or respiratory failure [1-3]. Venoarterial and venovenous extracorporeal devices require anticoagulant therapy to avoid thromboembolic complications, (for example, circuit thrombosis or pulmonary or systemic emboli) $[2,4]$. In addition, coagulation-cascade activation by the circuit and the membrane leads to platelet and coagulation-factor consumption, thereby

\footnotetext{
* Correspondence: charles-edouard.luyt@psl.aphp.fr

'Service de Réanimation, Institut de Cardiologie, Groupe Hospitalier PitiéSalpêtrière, Assistance Publique-Hôpitaux de Paris, 47, boulevard de l'Hôpital, 75651 Paris Cedex 13, France

Full list of author information is available at the end of the article
}

increasing the risk of bleeding [5]. Recently, it was suggested that von Willebrand factor abnormalities induced by extracorporeal circulation could trigger acquired von Willebrand syndrome and could explain, at least in part, the elevated bleeding rate in these patients [6]. Indeed, hemorrhaging represents the most-frequent severe adverse event in patients receiving extracorporeal circulatory or respiratory support, with reported rates up to $30 \%[2,4]$. Recombinant activated factor VII (rFVIIa; NovoSeven, Novo Nordisk, Copenhagen, Denmark) is a genetically engineered concentrate of human coagulation FVII that was originally designed to treat life-threatening hemorrhages in patients with hemophilia A or B [7]. To date, on-label indications of rFVIIa are prevention of

\section{() Biomed Central}


bleeding for surgical interventions or bleeding episodes in patients with either congenital hemophilia A or B with antibody inhibitors against standard-factor replacements, or acquired hemophilia, or congenital factor VII deficiency. In recent years, its off-label use has increased in cardiac surgery [8-10], liver transplantation [11], or trauma [12] without affecting mortality rates in those settings $[13,14]$. rFVIIa has also been used successfully in infants and adults receiving ECMO [15,16]. However, circuit thrombosis, fatal or not, has been described for ECMO patients given rFVIIa with or without other prothrombotic drugs $[17,18]$. Because clotting of the circuit is the second most frequent complication after bleeding, the use of fVIIa may increase this risk and thus be more deleterious than beneficial.

Because data are scarce on rFVIIa use in patients with ECMO, we retrospectively reviewed 15 consecutive patients administered rFVIIa for life-threatening intractable bleeding while receiving ECMO and reviewed all the cases reported in the literature. Intractable bleeding was defined as persistent bleeding although all medical and surgical means to control bleeding have been exhausted.

\section{Materials and methods \\ Patient selection and definitions}

In our 18-bed tertiary intens ive care unit (ICU), ECMO is widely used for patients in refractory cardiogenic shock (venoarterial ECMO) or refractory acute respiratory distress syndrome (ARDS) (venovenous ECMO) $[1,19,20]$. Data on patients who received rFVIIa while receiving ECMO were extracted and retrospectively analyzed. Patients who underwent ECMO during their ICU stay but received rFVIIa before ECMO implantation or after its removal were not included. The following data were extracted from our computerized charts and recorded: demographic characteristics at ICU admission; ECMO type (venoarterial or venovenous), and reason for implantation; bleeding site; blood products required (number of units of packed red cells (PRCs), platelets and fresh-frozen plasma (FFP); specific medical, surgical, or interventional radiology hemostatic measures applied to stop bleeding; and details regarding rFVIIa use (total dose, number of infusions).

In our institution, rFVIIa use adheres to guidelines recommending correction of coagulation parameters (prothrombin time $(\mathrm{PT})>50 \%$, activated partial thromboplastin time $(\mathrm{aPTT})$ ratio $<2$, platelets $>50,000 / \mathrm{ml}$, fibrinogen $>1 \mathrm{~g} / \mathrm{L}$ ), hypothermia (temperature $>36^{\circ} \mathrm{C}$ ), hypocalcemia (calcemia $>2.2 \mathrm{mM}$ ), and anemia (hematocrit $>24 \%$ ) before its infusion (Figure 1). Substitution limits for fibrinogen and platelets were $1 \mathrm{~g} / \mathrm{L}$ and 50,000/ $\mathrm{ml}$, respectively. Our institution protocol for rFVIIa infusion is to give the patient an initial dose of $60 \mu \mathrm{g} / \mathrm{kg}$, followed by a second dose of $60 \mu \mathrm{g} / \mathrm{kg}$ if the physician estimates that the bleeding does not stop. Factor XIII was never given, and we also never use antifibrinolytic agents such as tranexamic acid in such situations.

Number of blood products transfused (PRC, platelets, FFP, cryoprecipitate) and volume of chest-tube output (for patients with intrathoracic bleeding) were used to quantify bleeding. Volumes were recorded from 24 hours before until 24 hours after rFVIIa administration. In France, volumes of PRC, platelets, and FFP are 240 to $260 \mathrm{ml}, 200$ to $600 \mathrm{ml}$ (depending on platelet concentration), and 200 to $220 \mathrm{ml}$, respectively. rFVIIa efficacy against bleeding was defined by its control (if visually in circuits), the diminished need for blood-product transfusion, and no early recurrence.

The following thrombotic complications were defined as clinically relevant thrombotic episodes: ischemic stroke or peripheral arterial embolism in patients with venoarterial ECMO, pulmonary embolism for patients on venovenous ECMO (suspected in the case of hemodynamic instability, unexplained oxygenation decrease), or circuit and/or oxygenator thrombosis for both ECMO types (either a total thrombosis requiring urgent changing of the circuit or partial thrombosis responsible for hemolysis). Duration of mechanical ventilation, ICU length of stay, and ICU mortality also were recorded.

This epidemiologic study did not require ethical approval, in accordance with the ethical standards of our institution's Committee for the Protection of Human Research Subjects (CCP Ile de France VI, Groupe Hospitalier Pitié-Salpêtrière, Paris). In accordance with French law, no informed consent was obtained because this epidemiologic study did not modify existing diagnostic or therapeutic strategies.

\section{ECMO circuit and implantation}

The extracorporeal system consisted of polyvinyl chloride tubing, a membrane oxygenator (QuadroxBioline; Jostra-Maquet, Orléans, France; or Eos ECMO, Sorin, Milan, Italy), a centrifugal pump (Rotaflow, JostraMaquet, or Revolution, Sorin), and drainage and reinfusion cannulae (Biomedicus Carmeda, Medtronic, Boulogne-Billancourt, France, or Edwards Lifesciences, Irvine, CA, USA). An oxygen-air blender (Sechrist Industries, Anaheim, CA, USA) was used to ventilate the membrane oxygenator [1].

Two types of venoarterial ECMO were used: peripheral (femorofemoral) or central. In patients with peripheral ECMO, arterial and venous femoral cannulae were placed percutaneously or surgically. When the femoral artery caliber was small or signs of leg ischemia appeared, an additional 7Fr cannula was inserted distally 


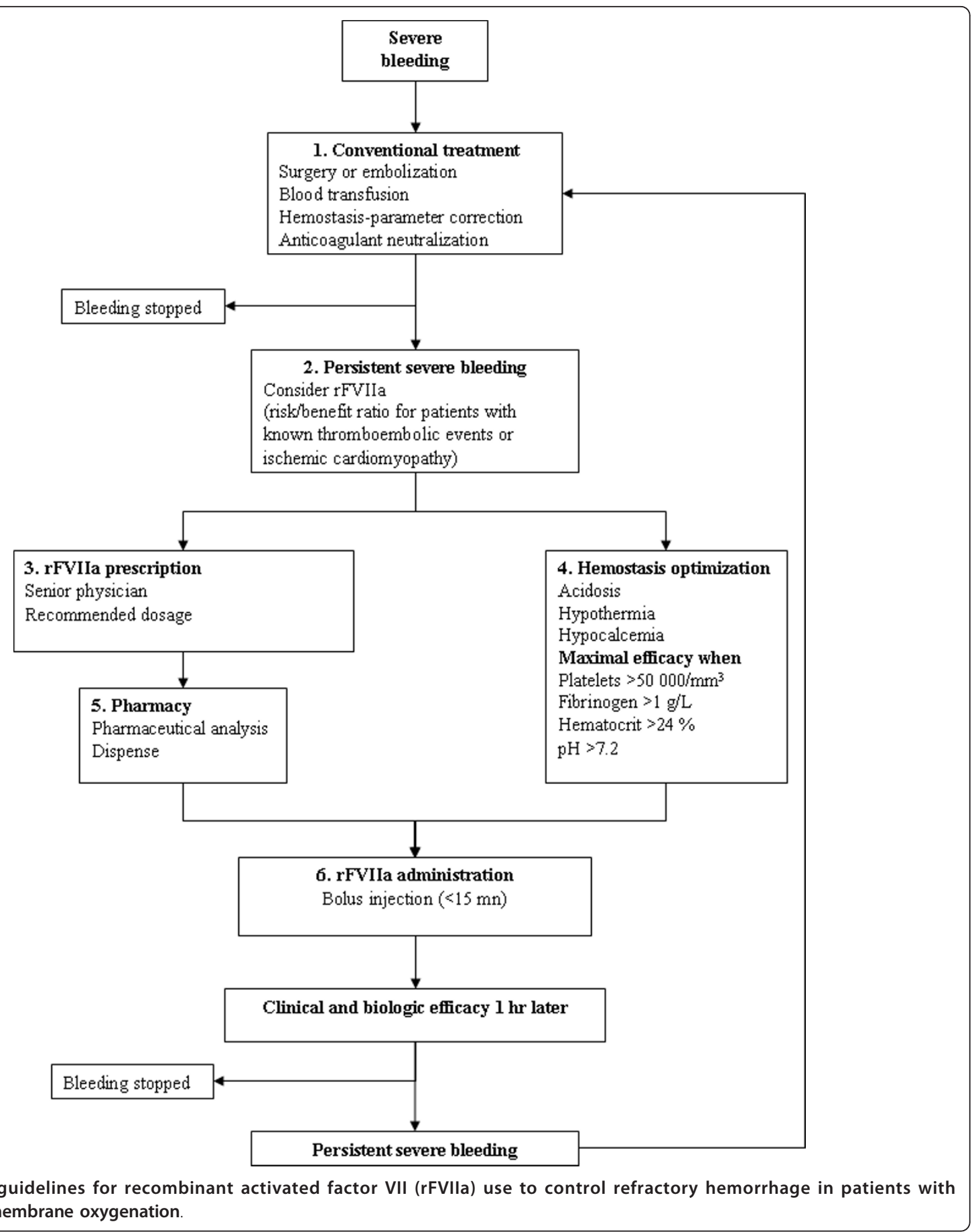

into the femoral artery to prevent or treat severe leg ischemia [1]. Patients with central ECMO had right atrial drainage and aortic reinfusion cannulae.

For venovenous ECMO, two-site cannulation was used, and all cannulae were inserted percutaneously. The drainage cannula was inserted into the femoral vein (extending into the inferior vena cava), and the reinfusion cannula was inserted into the internal jugular vein (extending into the right atrium).

\section{Patient management under ECMO}

All patients were continuously infused with unfractioned heparin to achieve an aPTT ratio $<1.5$ for venovenous ECMO and between 1.5 and 2 for venoarterial ECMO. 
No heparin bolus was injected at ECMO initiation. The heparin dose was adapted at least once daily, according the aPTT value and clinical tolerance; it was stopped when bleeding occurred and restarted after bleeding was controlled. The oxygenator membrane was changed when fibrin deposition or thrombi had deleterious effects on blood oxygenation, the platelets count decreased significantly $(<50,000 / \mathrm{ml})$, or hemolysis appeared. The circuit was checked daily by experienced perfusionists and changed when fibrin deposits or clots accumulated on the membrane, hemolysis or thrombopenia was observed, or blood oxygenation declined sharply, and systematically, every 8 to 10 days [1].

\section{Statistical analyses}

Gaussian variables are expressed as mean \pm SD, and non-gaussian variables, as medians $\left(25^{\text {th }}\right.$ to $75^{\text {th }}$ interquartile range (IQR)). Continuous variables were compared with the Student $t$ test or the Mann-Whitney $U$ test, as appropriate. Categoric variables were compared with the $\chi^{2}$ test. All $P$ values were two-tailed, and statistical significance was defined as $P<0.05$. Analyses were performed by using StatView 5.0 (SAS Institute Inc., Cary, NC, USA) and SPSS 11.5 (SPSS Inc., Chicago, IL, USA) software.

\section{Results}

\section{Study population}

From January 2006 to March 2011, 315 of our ICU patients underwent venoarterial ECMO and, 62, venovenous ECMO. Among these 377 patients, 15 (4\%) received rFVIIa while receiving ECMO. Four of them were supported with venovenous ECMO, and 11, 10 with preexisting cardiac disease, with venoarterial ECMO; their admission characteristics are listed in Table 1. Two patients were immunocompromised: an HIV-infected patient received venovenous ECMO, and an allogenic stem-cell transplantation recipient had venoarterial ECMO.

\section{Bleeding episode}

For $12(80 \%)$ patients (11 with venoarterial and one with venovenous ECMO), the source of bleeding was the surgical site (that is, mediastinal bleeding (all had a sternotomy, either for cardiac surgery or central ECMO cannulation)). The bleeding sources in the remaining three patients with venovenous ECMO are listed in Table 2. For all 15 patients, all medical and surgical means to control bleeding were exhausted before rFVIIa infusion: for the 12 patients with surgical sites, reinterventions excluded curable causes of bleeding; a patient with massive epistaxis received anterior and posterior nasopharyngeal packing; another with hemothorax required arterial embolization despite surgery because of
Table 1 Characteristics of the 15 patients

\begin{tabular}{|c|c|}
\hline Characteristic & Value \\
\hline Male sex & $10(66.7)$ \\
\hline Age (years) & $47(32-53)$ \\
\hline SAPS $\|$ at admission & $79(62-90)$ \\
\hline SOFA at admission & $15(10-17)$ \\
\hline McCabe \& Jackson comorbidity score & $0(0-1)$ \\
\hline$<2$ & $12(80)$ \\
\hline$\geq 2$ & 3 \\
\hline \multicolumn{2}{|l|}{ Reason for ECMO } \\
\hline Venoarterial ECMO & $11(73.3)$ \\
\hline Postcardiotomy cardiogenic shock & 5 \\
\hline Cardiac transplantation & 1 \\
\hline Infarction-related cardiogenic shock & 3 \\
\hline Myocarditis & 2 \\
\hline Venovenous ECMO for ARDS & $4(26.7)$ \\
\hline Pneumonia & 3 \\
\hline Acute pancreatitis & 1 \\
\hline \multicolumn{2}{|l|}{ Underlying disease } \\
\hline Preexisting heart disease & $10(66.7)$ \\
\hline Ischemic cardiomyopathy & 4 \\
\hline Nonischemic dilated cardiomyopathy & 2 \\
\hline Valvular cardiomyopathy & 1 \\
\hline Hypertension-related cardiomyopathy & 2 \\
\hline Congenital heart disease & 1 \\
\hline Diabetes mellitus & $1(6.7)$ \\
\hline Obesity (BMl > $30 \mathrm{~kg} / \mathrm{m}^{-2}$ ) & $3(20)$ \\
\hline $30<\mathrm{BMl}<35$ & 2 \\
\hline $35<\mathrm{BMI}<40$ & 1 \\
\hline $\mathrm{BMI}>40$ & 0 \\
\hline Immunocompromised & $2(13)$ \\
\hline HIV infected & 1 \\
\hline Allogenic stem-cell transplantation & 1 \\
\hline
\end{tabular}

Data are expressed as $n$ (\%) or median (IQR). ARDS, acute respiratory distress syndrome; BMI, body mass index; ECMO, extracorporeal membrane oxygenation; HIV, human immunodeficiency virus; SAPS, simplified acute physiology score; SOFA, sequential organ-failure assessment.

persistent bleeding; and the last had uterine polyprelated hemorrhage treated with arterial embolization. These measures failed to control bleeding, as attested to by their transfusion requirements within the 24 hours preceding rFVIIa. Before rFVIIa injection, hemostasis parameters, body temperature, $\mathrm{pH}$, and calcemia were within acceptable ranges recommended by our guidelines and the manufacturer for rFVIIa infusion. All patients received the same dosage for each rFVIIa infusion according to our institution guidelines, without protocol violation, (that is, a dose of $60 \mu \mathrm{g} / \mathrm{kg}$ for each infusion). Ten patients received one rFVIIa infusion, three received two, one required three, and the last was given four. Patients received a median rFVIIa dose of 77 (54 to 144$) \mu g / \mathrm{kg}$. 
Table 2 Bleeding characteristics and treatments administered to the $\mathbf{1 5}$ patients

\begin{tabular}{|c|c|c|}
\hline Parameter & \multicolumn{2}{|c|}{ Value } \\
\hline \multicolumn{3}{|l|}{ Site of bleeding } \\
\hline \multicolumn{3}{|l|}{ Venoarterial ECMO } \\
\hline Mediastinal (post-surgery) & \multicolumn{2}{|c|}{$11(73.3)$} \\
\hline \multicolumn{3}{|l|}{ Venovenous ECMO } \\
\hline Mediastinal (post-surgery) & \multicolumn{2}{|c|}{1} \\
\hline Hemothorax & \multicolumn{2}{|c|}{1} \\
\hline Gynecologic & \multicolumn{2}{|c|}{1} \\
\hline Epistaxis & \multicolumn{2}{|c|}{1} \\
\hline \multicolumn{3}{|l|}{ Transfusion required } \\
\hline Packed red blood cell & \multicolumn{2}{|c|}{$17(13.5-19)$} \\
\hline Fresh-frozen plasma & \multicolumn{2}{|c|}{$14(9-21.5)$} \\
\hline Concentrated platelets & \multicolumn{2}{|c|}{$5(3-8)$} \\
\hline $\begin{array}{l}\text { Biologic parameters before and } \\
\text { after rFVIla infusion }\end{array}$ & Before & After \\
\hline Hemoglobin & $7.5(7.1-8.6)$ & $9(8.2-9.8)$ \\
\hline Platelets & $83(61-117)$ & $68(61-106)$ \\
\hline PT & $46(42-52)$ & $101(54-120)$ \\
\hline aPTT & $1.7(1.4-2.2)$ & $1.4(1.2-1.9)$ \\
\hline Ionized calcemia & $1.10(1.05-1.20)$ & $1.17(1.03-1.28$ \\
\hline $\mathrm{pH}$ & $7.37(7.28-7.42)$ & $7.41(7.34-7.47)$ \\
\hline Temperature before rFVIla infusion $\left({ }^{\circ} \mathrm{C}\right)$ & \multicolumn{2}{|c|}{$36.4(34.3-37.1)$} \\
\hline rFVlla dose infused $(\mu \mathrm{g} / \mathrm{kg})$ & \multicolumn{2}{|c|}{77 (54-144) } \\
\hline \multicolumn{3}{|l|}{$\begin{array}{l}\text { Number of injections of rFVlla, number } \\
\text { of patients }\end{array}$} \\
\hline 1 & \multicolumn{2}{|c|}{10} \\
\hline 2 & \multicolumn{2}{|c|}{3} \\
\hline 3 & \multicolumn{2}{|c|}{1} \\
\hline 4 & \multicolumn{2}{|c|}{1} \\
\hline
\end{tabular}

Data are expressed as number (\%) or medians (IQR). aPTT, activated thromboplastin time; ECMO, extracorporeal membrane oxygenation; PT, prothrombin time; rFVIIA, recombinant factor VIla.

\section{Bleeding control}

For 14 patients, bleeding dramatically decreased after rFVIIa infusion, as shown by the diminished need for blood products. Compared with the 24-hour period before rFVIIa infusion, RBC administration decreased a median of $75 \%$ (56.5\% to $81 \%$ ], and FFP declined $84 \%$ (67\% to $100 \%)$ within the following 24 hours $(P=$ 0.0008) (Figure 2). Moreover, for the 10 patients whose blood loss could be quantified, chest-tube output decreased from 2,057 (1,010 to 4,381) $\mathrm{ml}$ during the 24 hours before rFVIIa infusion to 850 (622 to 1,356 ] $\mathrm{ml}$ during the 24 hours after $(P=0.008)$. The patient whose bleeding persisted despite surgical intervention, arterial embolization, and rFVIIa infusion, underwent another surgical procedure; the surgeon found active bleeding of an injured intercostal artery that was finally controlled with vascular repair.

\section{rFVIla-related thrombotic events}

No clinical signs of thrombosis were observed after rFVIIa infusion. Two circuits in patients with venoarterial ECMO were changed within the 48 hours after rFVIIa infusion because of fibrin deposits and related hemolysis, but no massive circuit thrombosis occurred. One patient progressed to brain death during the 24 hours after the infusion, and because no brain CT scan was performed, an ischemic stroke could not be ruled out.

\section{Outcomes}

The median durations of ECMO, mechanical ventilation, and ICU stay were 13 (6 to 37), 45 (6 to 49], and 54 (6 to 55) days, respectively. Nine (60\%) of the 15 patients died, eight who had venoarterial ECMO; four developed multiorgan failure 1 ( 0 to 2 ) days after and despite controlling the hemorrhage; three patients died of septic shock 21 (14 to 88) days after bleeding stopped; two died of brain death within 24 hours after rFVIIa infusion, one of a cerebral hemorrhage (the possibility of an ischemic stroke with secondary conversion to a hemorrhagic stroke was ruled out by two experts, based on CT scan), and the other of unknown etiology. The only patient whose hemorrhage was not controlled by rFVIIa had active bleeding of an injured intercostal artery that was surgically repaired; he was discharged alive after > 100 days in the ICU.

\section{Discussion}

Herein, we describe our experience with rFVIIa for refractory bleeding in 15 patients receiving ECMO. For 14 patients, bleeding dramatically decreased after rFVIIa infusion without relapse. Although no massive thrombotic events were observed in our patients, two ECMO circuits were changed during the 48 hours after rFVIIa administration because of oxygenator clotting that may have resulted from this procoagulant treatment. Those circuits were changed 8 and 11 days after ECMO initiation, which, in our experience, may be the normal lifetime of membranes. Moreover, one patient progressed to brain death early after rFVIIa infusion, and because ischemic stroke could not be excluded as its cause, a thrombotic complication could not be ruled out. However, another explanation in this patient could be a cerebral hemorrhage as the cause of death. If so, and despite the use of rFVIIa, the rate of cerebral hemorrhage in this population would be very high (13\%). Although mortality was high, $40 \%$ of our patients with intractable bleeding survived. As a comparison, the survival rate of other ECMO patients (not having received rFVIIa) during the same time period in our unit was $55 \%$ (difference not statistically significant) [21]. 


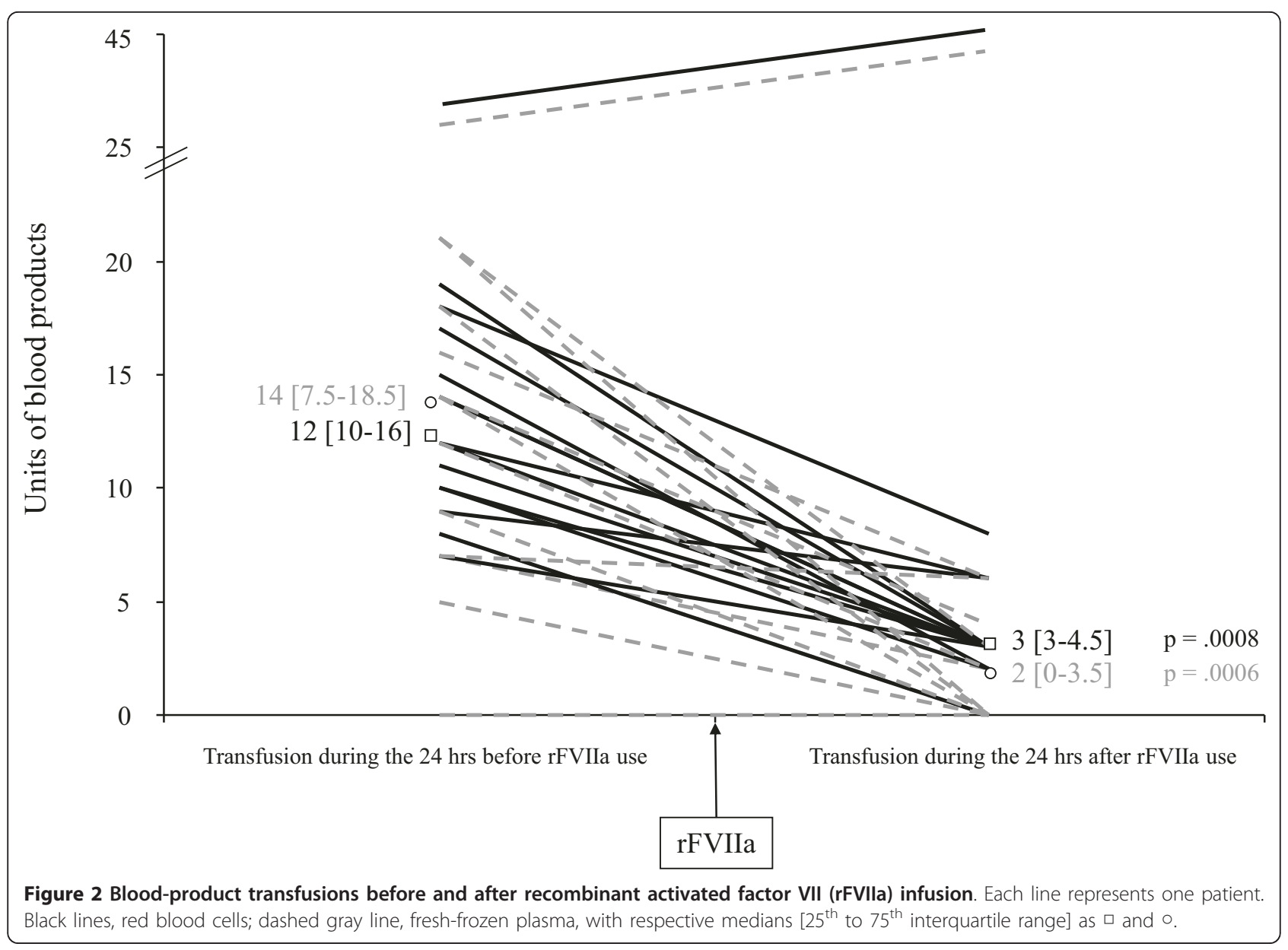

To the best of our knowledge, we report the largest cohort of adult ECMO patients treated with rFVIIa. Several reports are available in the literature, nine of them focusing on pediatric patients (for a total of 48 infants) and six on adults (for a total of 9 adults) [15-18,22-30] (Table 3). All authors concurred about its control of bleeding and decrease of blood-products requirements. Some patients experienced circuit thromboses or oxygenator failure, and eight had systemic thromboses or emboli. Most events occurred in pediatric patients, and another procoagulant treatment was given in some cases. rFVIIa was given in doses ranging from 40 to 220 $\mu \mathrm{g} / \mathrm{kg}$. For the 26 patients for whom these data were available, eight who experienced thrombotic events had not received higher doses than had those without: 90 $\mu \mathrm{g} / \mathrm{kg}$ (83 to 141 ) versus $192 \mu \mathrm{g} / \mathrm{kg}$ (93 to 252 ), respectively $(P=0.46)$. In our patients, except for one patient who progressed to brain death and in whom a major stroke could not be ruled out, no major thrombotic episode occurred. However, we did not measure thrombosis and fibrinolysis with thromboelastogram, D-dimer, or other tests. We thus cannot exclude that in some patients, the development of multiorgan failure may be related to, or have been favored by microthrombosis of end organs, and that this may have affected the mortality. Nevertheless, the lack of thrombotic complications in our patients contrasts with the high rate quoted in the literature. We can only speculate on the causes of this difference. We do not think it could be related to the dose of rFVIIa, because patients who experienced thrombotic events in the literature had not received higher doses than had ours. Interestingly, most thrombotic episodes occurred in pediatric patients: of the 16 patients who experienced a major thrombotic event, 14 were infants (30\% of this population), and only two were adults ( $22 \%$ of this population). This higher rate in pediatric patients may be explained by differences in circuit size and by differences of clotting system between infants and adults.

Many possibilities could explain bleeding in ECMO patients. First, surgeries before, after, or during ECMO are potential sites of bleeding. Second, even with percutaneous cannulation, the insertion site is another potential source of bleeding [2]. Third, coagulation disorders in patients on ECMO may be caused by heparin use, activation of platelets, and coagulation factors on the 
Table 3 Studies reporting pediatric and adult patients received rFVIla while receiving ECMO

\begin{tabular}{|c|c|c|c|c|c|c|c|}
\hline Study & Number & $\begin{array}{c}\text { Age, } \\
\text { median } \\
\text { (IQR) }\end{array}$ & $\begin{array}{c}\mathrm{rFVlla} \\
\text { dose } \\
(\mu \mathrm{g} / \mathrm{kg})\end{array}$ & $\begin{array}{l}\text { rFVIla doses } \\
\text { received, } \\
\text { number }\end{array}$ & $\begin{array}{c}\text { Effect on blood-product requirements or } \\
\text { bleeding }\end{array}$ & $\begin{array}{l}\text { Thrombotic } \\
\text { events }\end{array}$ & $\begin{array}{l}\text { Deaths, } \\
\text { number }\end{array}$ \\
\hline \multicolumn{8}{|c|}{ Pediatric patients } \\
\hline $\begin{array}{l}\text { Wittenstein } \\
\text { et al. [30] }\end{array}$ & 4 & $\begin{array}{l}0.625(0.25- \\
9) \text { months }\end{array}$ & $90-120$ & 2 & $\begin{array}{c}\downarrow 81.9 \% \text { PRC between before and after one } \\
\text { rFVIla infusion } \\
\begin{array}{c}\downarrow 90 \% \text { FFP between before and after one rFVIlla } \\
\text { infusion }\end{array}\end{array}$ & 0 & 0 \\
\hline $\begin{array}{l}\text { Velik- } \\
\text { Salchner } \\
\text { et al. [29] }\end{array}$ & 1 & 0.5 months & 90 & 1 & Bleeding stopped & 1 (arterial) & 1 \\
\hline $\begin{array}{l}\text { Dominguez } \\
\text { et al. [24] }\end{array}$ & 2 & $\begin{array}{l}11 \text { and } 13 \\
\text { years }\end{array}$ & 90 & 3 and 10 & $\begin{array}{c}\downarrow 88.7 \% \text { total blood products between } 12 \text { hours } \\
\text { before and after rFVlla infusion for case } 1 \\
\downarrow 46.7 \% \text { total blood products between } 24 \text { hours } \\
\text { before and after rFVlla infusion for case } 2\end{array}$ & 0 & 1 \\
\hline $\begin{array}{l}\text { Veldman } \\
\text { et al. [16] }\end{array}$ & 7 & $\begin{array}{l}4 \text { (0.4-14.5) } \\
\text { months }\end{array}$ & $\begin{array}{l}83(61- \\
106)\end{array}$ & $3(2-3.5)$ & $\begin{array}{c}\downarrow 23.1 \% \text { PRC between before and after one } \\
\text { rFVlla infusion } \\
\begin{array}{c}\downarrow 35.3 \% \text { FFP between before and after one } \\
\text { rFVIla infusion }\end{array}\end{array}$ & 0 & 3 \\
\hline $\begin{array}{l}\text { Argawal } \\
\text { et al. [22] }\end{array}$ & $11^{\mathrm{a}}$ & 9.5 days & $\begin{array}{c}36.5 \pm \\
18.2\end{array}$ & $1.6 \pm 7$ & $\begin{array}{c}\downarrow 42 \% \text { PRC between before and after one rFVlla } \\
\text { infusion }(P<0.05) \\
\downarrow 599.3 \% \text { FFP between before and after one } \\
\text { rFVlla infusion }(P<.05)\end{array}$ & $\begin{array}{l}2 \text { circuit } \\
\text { thromboses }\end{array}$ & 3 \\
\hline $\begin{array}{l}\text { Chalwin } \\
\text { et al. [23] }\end{array}$ & 1 & 18 months & 90 & 1 & Bleeding stopped & $\begin{array}{l}1 \text { circuit } \\
\text { thrombosis }\end{array}$ & 1 \\
\hline $\begin{array}{l}\text { Guzzeta } \\
\text { et al. [26] }\end{array}$ & 1 & 5 days & 70 & 2 & $\begin{array}{c}\downarrow 66.7 \% \text { PRC after the two rFVlla doses } \\
\quad \downarrow 100 \% \text { FFP after two rFVIla doses }\end{array}$ & $\begin{array}{l}1 \text { extensive distal } \\
\text { thrombotic emboli }\end{array}$ & 1 \\
\hline $\begin{array}{l}\text { Schneider } \\
\text { et al. [28] }\end{array}$ & $4^{\mathrm{b}}$ & $\begin{array}{l}6.7(1-11.2) \\
\text { years }\end{array}$ & $\begin{array}{c}180 \\
(146.25- \\
180)\end{array}$ & $2(1.75-2)$ & $\begin{array}{c}\downarrow 46.5 \% \text { (-71.25 to }-2.25) \text { PRC between } 12 \text { hours } \\
\text { before and after rFVIla infusion } \\
14.5 \% \text { (-49.5 to } 21.5) \text { FFP between } 24 \text { hours } \\
\text { before and after rFVIla infusion }\end{array}$ & 1 stroke & 2 \\
\hline $\begin{array}{c}\text { Niebler et al. } \\
\text { [27] }\end{array}$ & 17 & $\begin{array}{l}0.1(0-14) \\
\text { years }\end{array}$ & $45-90$ & $1.5(1-2)$ & $\begin{array}{l}\downarrow 50 \% \text { total blood products between before and } \\
\text { after rFVlla infusion } \\
\qquad(P=0.05)\end{array}$ & $\begin{array}{c}4 \text { clinical } \\
\text { thromboses } \\
2 \text { oxygenator } \\
\text { failures } \\
2 \text { circuit } \\
\text { obstructions }\end{array}$ & 12 \\
\hline \multicolumn{8}{|l|}{ Adult patients } \\
\hline $\begin{array}{l}\text { Bui et al. } \\
\text { [17] }\end{array}$ & 1 & 56 years & 146.5 & 2 & $\begin{array}{l}\downarrow 53.8 \% \text { PRC between the } 12 \text { hours before and } \\
\text { after rFVlla infusion } \\
\begin{array}{c}\downarrow 16.7 \% \text { FFP between } 12 \text { hours before and after } \\
\text { rFVIla infusion }\end{array}\end{array}$ & $\begin{array}{l}1 \text { circuit } \\
\text { thrombosis }\end{array}$ & 1 \\
\hline $\begin{array}{l}\text { Brose et al. } \\
\quad[15]\end{array}$ & 1 & 17 years & 220 & 2 & $\begin{array}{c}\text { Bleeding stopped ( } \downarrow \text { } \downarrow 90 \% \text { bleeding after rFVIla } \\
\text { infusion) }\end{array}$ & 0 & 0 \\
\hline $\begin{array}{l}\text { Schneider } \\
\text { et al. [28] }\end{array}$ & $5^{\mathrm{b}}$ & $\begin{array}{l}48(45.2-52) \\
\text { years }\end{array}$ & $\begin{array}{l}90(54- \\
105)\end{array}$ & $2(1-2)$ & $\begin{array}{c}\downarrow 61 \% \text { (-79 to }-47) \text { PRC between the } 12 \text { hours } \\
\text { before and after rFVIla infusion } \\
\downarrow 33 \% \text { (-58 to 42) FFP between the } 24 \text { hours } \\
\text { before and after injection of rFVlla }\end{array}$ & 0 & 3 \\
\hline $\begin{array}{l}\text { Syburra } \\
\text { et al. [35] }\end{array}$ & 1 & 58 years & 84.7 & 1 & Bleeding stopped & $\begin{array}{l}1 \text { left atrium } \\
\text { thrombosis }\end{array}$ & 1 \\
\hline $\begin{array}{l}\text { Dunne et al. } \\
\quad[25]\end{array}$ & 1 & 63 years & 47 & 1 & $\begin{array}{c}\text { Bleeding stopped ( } \downarrow \text { ( } 90 \% \text { bleeding after rFVIla } \\
\text { infusion) }\end{array}$ & 0 & 0 \\
\hline
\end{tabular}

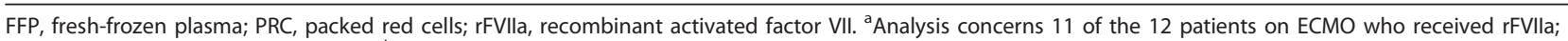
one patient did not respond to $\mathrm{rFVlla}$. ${ }^{\mathrm{b}}$ The authors reported on 12 patients, among whom four were infants with ECMO, five were adults with ECMO, and three were adults with ventricle-assist devices.

oxygenator membrane and/or specific coagulation-factor abnormalities. In addition to impaired platelet function, patients receiving ECMO may develop acquired von Willebrand syndrome [6]; shear stress during extracorporeal support is responsible for conformational modifications of von Willebrand factor that becomes exposed to metalloprotease-mediated cleavage [31]. The resulting truncated von Willebrand factor no longer has procoagulant activity [31]. A recent study by Heilmann et al. [6] clearly demonstrated that patients with ECMO 
developed acquired von Willebrand syndrome, whereas patients without any such support did not. Because of these coagulation disorders, the coagulation system should be closely monitored in patients with ECMO, to avoid bleeding but also thrombotic complications.

Logan et al. [32] recently evaluated off-label rFVIIa use in patients with intractable bleeding (2000 to 2008) and found that, in US hospitals, its use increased $>140$ fold, so that in $2008,97 \%$ of in-hospital administrations were off-label. Moreover, Yank et al. [14] evaluated the benefits and disadvantages of rFVIIa use for five offlabel indications: intracranial hemorrhage, cardiac surgery, trauma, liver transplantation, and prostatectomy. They reported that, for intracranial hemorrhage, survival was not improved with rFVIIa use across a range of doses, but the arterial embolism rate increased; cardiac surgery-associated mortality was unchanged, but risk of thromboembolism was increased; and posttrauma mortality and thromboembolism rates were unaffected, but the ARDS risk was lower. Primary clotting disorders represented roughly $5 \%$ of off-label rFVIIa use in this recent analysis [14]. rFVIIa is an effective agent to treat refractory bleeding in von Willebrand disease patients and to treat or prevent bleeding in patients with alloantibodies or autoantibodies directed against von Willebrand factor [33]. According to a recent review, the positive response rate was $96 \%$, with a low frequency of adverse events (only one case of myocardial infarction in a patient with type $2 \mathrm{~A}$ von Willebrand disease) [34]. However, major thrombotic events can occur [35]. Thus, rFVIIa might be a potential therapeutic option for patients receiving ECMO with intractable bleeding despite conventional treatment (including normalization of coagulation parameters, surgery, and embolization), but clinicians must be aware of possible life-threatening systemic thrombosis, emboli, or circuit clotting.

Our study has several limitations. First, although it is the largest study to date, it is a small single-center study. However, the number of reported patients who received rFVIIa remains relatively low.

Second, because of its retrospective design, our study carries the inherent bias of this type of study. For example, bleeding control could be the natural evolution of the refractory bleeding episode due to coagulation optimization and/or interventional treatment rather than true rFVIIa efficacy. Nevertheless, our data on diminished blood-product needs and chest-drainage output clearly support rFVIIa efficacy, in agreement with the available literature.

Third, our study lacks a control group. Having a control group of ECMO patients with intractable bleeding but not treated with rFVIIa might have helped to determine whether the outcome would have been better with rFVIIa. However, because this disease is not frequent and because all patients with intractable bleeding received rFVIIa, this comparison is not possible.

Fourth, except for standard coagulation tests like aPTT or PT, we did not explore coagulation abnormalities more extensively, particularly in light of the recent description of acquired von Willebrand syndrome. Moreover, we did not measure von Willebrand antigen, ristocetin-cofactor activity, and collagen-binding capacity, known to be decreased in ECMO patients [6].

Fifth, rFVIIa use in ECMO patients remains off-label. Because of the scarcity of such cases, a randomized study to evaluate rFVIIa benefit in patients with persistent bleeding under ECMO is excluded. Although it seems, based on our patients and the literature, that rFVIIa may be useful in ECMO patients to stop bleeding, whether its use decreases mortality rate in this particular setting remains to be determined.

Last, because of our population, the results presented here apply mostly to bleeding in the setting of venoarterial ECMO and to surgical-site bleeding.

\section{Conclusions}

In our experience, rFVIIa use for patients with ECMO with intractable bleeding was associated with bleeding control and decreased blood-product requirements. Except one patient who progressed to brain death and in whom a major stroke could not be ruled out, no major thrombotic episode occurred, but such events have been reported, mostly in pediatric patients, without any dose/effect relation. Despite a high mortality, $40 \%$ of our patients survived, similar to the previously published rate [15-18,22-30], and without statistical difference as compared with the $55 \%$ survival rate of our ECMO patients who did not receive rFVIIa. Therefore, we conclude that rFVIIa may be used to control refractory bleeding in patients receiving ECMO. However, its use should be considered, and clinicians should be aware of the risk of potentially life-threatening systemic thrombosis, emboli, or circuit clotting. Whether rFVIIa use in such patients may save lives remains to be determined.

\section{Key messages}

- rFVIIa may be used to control intractable bleeding in ECMO patients.

- Before its use, clinicians should exhaust all medical and surgical means to control bleeding.

- Clinicians should be aware of the risk of major thrombotic events after rFVIIa.

- Whether rFVIIa may save lives in this population has not been determined.

- The coagulation system should be closely monitored in patients with ECMO to avoid bleeding and thrombotic complications. 


\section{Abbreviations}

aPTT: activated partial thromboplastin time; ARDS: acute respiratory distress syndrome; ECMO: extracorporeal membrane oxygenation; FFP: fresh-frozen plasma; ICU: intensive care unit; PT: prothrombin time; PRCs: packed red cells; rFVIla: recombinant activated factor VII.

\section{Authors' contributions}

$X R, S M A, N B, J L T, P L, J C, A C$, and CEL contributed to conception and design of the study. XR, SMA, NB, and CEL collected, analyzed, and interpreted the data. $X R, J C, A C$, and CEL drafted the manuscript. NB, JLT, and PL were involved in revising the manuscript critically for important intellectual content. All authors read and approved the final manuscript.

\section{Competing interests}

The authors declare that they have no competing interests in relation to the present manuscript.

\section{Acknowledgements}

The authors thank Janet Jacobson for writing assistance during the production of this manuscript.

\section{Author details}

'Service de Réanimation, Institut de Cardiologie, Groupe Hospitalier PitiéSalpêtrière, Assistance Publique-Hôpitaux de Paris, 47, boulevard de I'Hôpital, 75651 Paris Cedex 13, France. ${ }^{2}$ Service de Chirurgie Thoracique et Cardiovasculaire, Institut de Cardiologie, Groupe Hospitalier Pitié-Salpêtrière, Assistance Publique-Hôpitaux de Paris, 47, boulevard de l'Hôpital, 75651 Paris Cedex 13, France. ${ }^{3}$ Université Paris 6-Pierre et Marie Curie, Sorbonne Universités, 4 place Jussieu, 75005 Paris, France.

Received: 20 December 2012 Revised: 20 February 2013

Accepted: 22 March 2013 Published: 25 March 2013

\section{References}

1. Combes A, Leprince P, Luyt CE, Bonnet N, Trouillet JL, Leger P, Pavie A, Chastre J: Outcomes and long-term quality-of-life of patients supported by extracorporeal membrane oxygenation for refractory cardiogenic shock. Crit Care Med 2008, 36:1404-1411.

2. Gaffney AM, Wildhirt SM, Griffin MJ, Annich GM, Radomski MW: Extracorporeal life support. BMJ 2010, 341:C5317.

3. Marasco SF, Lukas G, McDonald M, McMillan J, Ihle B: Review of ECMO (extra corporeal membrane oxygenation) support in critically ill adult patients. Heart Lung Circ 2008, 17(Suppl 4):S41-S47.

4. Brogan TV, Thiagarajan RR, Rycus PT, Bartlett RH, Bratton SL: Extracorporeal membrane oxygenation in adults with severe respiratory failure: a multicenter database. Intensive Care Med 2009, 35:2105-2114.

5. Oliver WC: Anticoagulation and coagulation management for ECMO. Semin Cardiothorac Vasc Anesth 2009, 13:154-175.

6. Heilmann C, Geisen U, Beyersdorf F, Nakamura L, Benk C, Trummer G, Berchtold-Herz M, Schlensak C, Zieger B: Acquired von Willebrand syndrome in patients with extracorporeal life support (ECLS). Intensive Care Med 2012, 38:62-68.

7. Hedner U: Treatment of patients with factor VIII and factor IX inhibitors with special focus on the use of recombinant factor Vlla. Thromb Haemost 1999, 82:531-539.

8. Mitra B, Phillips L, Cameron PA, Billah B, Reid C: The safety of recombinant factor VIla in cardiac surgery. Anaesth Intensive Care 2010, 38:671-677.

9. Stanworth SJ, Birchall J, Doree CJ, Hyde C: Recombinant factor VIla for the prevention and treatment of bleeding in patients without haemophilia. Cochrane Database Syst Rev 2007, CD005011.

10. Tanaka KA, Waly AA, Cooper WA, Levy JH: Treatment of excessive bleeding in Jehovah's Witness patients after cardiac surgery with recombinant factor VIla (NovoSeven). Anesthesiology 2003, 98:1513-1515.

11. Hendriks HG, Meijer K, de Wolf JT, Klompmaker IJ, Porte RJ, de Kam PJ, Hagenaars AJ, Melsen T, Slooff MJ, van der Meer J: Reduced transfusion requirements by recombinant factor Vlla in orthotopic liver transplantation: a pilot study. Transplantation 2001, 71:402-405

12. Scher C, Narine V, Chien D: Recombinant factor Vlla in trauma patients without coagulation disorders. Anesthesiol Clin 2010, 28:681-690.
13. Stein DM, Dutton RP, O'Connor J, Alexander M, Scalea TM: Determinants of futility of administration of recombinant factor Vlla in trauma. J Trauma 2005, 59:609-615.

14. Yank V, Tuohy CV, Logan AC, Bravata DM, Staudenmayer K, Eisenhut $R$, Sundaram V, McMahon D, Olkin I, McDonald KM, Owens DK, Stafford RS: Systematic review: benefits and harms of in-hospital use of recombinant factor VIla for off-label indications. Ann Intern Med 2011, 154:529-540.

15. Brose $\mathrm{S}$, Sirbu $H$, Engel M, Kuhlen $R$, Autschbach R: Successful use of recombinant factor VIla in a patient with intractable bleeding during extracorporeal membrane oxygenation. Thorac Cardiovasc Surg 2005, 53:389-390.

16. Veldman A, Neuhaeuser C, Akintuerk H, Thul J, Gehron J, Schranz D, MichelBehnke I: $\mathrm{rFVlla}$ in the treatment of persistent hemorrhage in pediatric patients on ECMO following surgery for congenital heart disease. Paediatr Anaesth 2007, 17:1176-1181.

17. Bui JD, Despotis GD, Trulock EP, Patterson GA, Goodnough LT: Fatal thrombosis after administration of activated prothrombin complex concentrates in a patient supported by extracorporeal membrane oxygenation who had received activated recombinant factor VII. J Thorac Cardiovasc Surg 2002, 124:852-854.

18. Syburra T, Lachat M, Genoni M, Wilhelm MJ: Fatal outcome of recombinant factor Vlla in heart transplantation with extracorporeal membrane oxygenation. Ann Thorac Surg 2010, 89:1643-1645.

19. Luyt $C E$, Combes $A$, Becquemin MH, Beigelman-Aubry C, Hatem S, Brun AL, Zraik N, Carrat F, Grenier PA, Richard JC, Mercat A, Brochard L, BrunBuisson C, Chastre J, REVA Study Group: Long-term outcomes of pandemic 2009 influenza A (H1N1)-associated severe acute respiratory distress syndrome. Chest 2012, 142:583-592.

20. Mirabel M, Luyt CE, Leprince P, Trouillet JL, Leger P, Pavie A, Chastre J, Combes A: Outcomes, long-term quality of life, and psychologic assessment of fulminant myocarditis patients rescued by mechanical circulatory support. Crit Care Med 2011, 39:1029-1035.

21. Schmidt M, Bréchot N, Hariri S, Guiquet M, Luyt CE, Makri R, Leprince $P$ Trouillet JL, Pavie A, Chastre J, Combes A: Nosocomial infections in adult cardiogenic shock patients supported by venoarterial extracorporeal membrane oxygenation. Clin Infect Dis 2012, 55:1633-1641.

22. Agarwal HS, Bennett JE, Churchwell KB, Christian KG, Drinkwater DC Jr, He Y, Taylor MB: Recombinant factor seven therapy for postoperative bleeding in neonatal and pediatric cardiac surgery. Ann Thorac Surg 2007, 84:161-168.

23. Chalwin RP, Tiruvoipati R, Peek GJ: Fatal thrombosis with activated factor VII in a paediatric patient on extracorporeal membrane oxygenation. Eur J Cardiothorac Surg 2008, 34:685-686.

24. Dominguez TE, Mitchell M, Friess SH, Huh JW, Manno CS, Ravishankar C Gaynor JW, Tabbutt S: Use of recombinant factor Vlla for refractory hemorrhage during extracorporeal membrane oxygenation. Pediatr Crit Care Med 2005, 6:348-351.

25. Dunne B, Xiao P, Andrews D: Successful use of factor Vlla to control lifethreatening post-operative haemorrhage in a patient on extra-corporeal membrane oxygenation. Heart Lung Circ 2012, 21:229-230.

26. Guzzetta NA, Huch S, Fernandez JD, Tosone SR, Miller BE: Use of recombinant factor VIlla for uncontrolled bleeding in neonates after cardiopulmonary bypass. Paediatr Anaesth 2009, 19:364-370.

27. Niebler RA, Punzalan RC, Marchan M, Lankiewicz MW: Activated recombinant factor VII for refractory bleeding during extracorporeal membrane oxygenation. Pediatr Crit Care Med 2010, 11:98-102.

28. Schneider AG, Perez MH, Tozzi P, Voirol P, Schoettker P, AngelilloScherrer A, Cotting J, Von Segesser L, Eggimann P: Recombinant factor Vlla for intractable life-threatening bleeding in patients with circulatory assist devices. Intensive Care Med 2010, 36:1620-1621.

29. Velik-Salchner C, Sergi C, Fries D, Moser P, Streif W, Kolbitsch C: Use of recombinant factor Vlla (Novoseven) in combination with other coagulation products led to a thrombotic occlusion of the truncus brachiocephalicus in a neonate supported by extracorporal membrane oxygenation. Anesth Analg 2005, 101:924.

30. Wittenstein B, Ng C, Ravn H, Goldman A: Recombinant factor VII for severe bleeding during extracorporeal membrane oxygenation following open heart surgery. Pediatr Crit Care Med 2005, 6:473-476.

31. Akiyama M, Takeda S, Kokame K, Takagi J, Miyata T: Crystal structures of the noncatalytic domains of ADAMTS13 reveal multiple discontinuous 
exosites for von Willebrand factor. Proc Natl Acad Sci USA 2009, 106:19274-19279.

32. Logan AC, Yank V, Stafford RS: Off-label use of recombinant factor VIla in U.S. hospitals: analysis of hospital records. Ann Intern Med 2011, 154:516-522.

33. Franchini M, Veneri D, Lippi G: The use of recombinant activated factor VII in congenital and acquired von Willebrand disease. Blood Coagul Fibrinol 2006, 17:615-619.

34. Tiede A, Rand JH, Budde U, Ganser A, Federici AB: How I treat the acquired von Willebrand syndrome. Blood 2011, 117:6777-6785.

35. Basso IN, Keeling D: Myocardial infarction following recombinant activated factor VII in a patient with type $2 \mathrm{~A}$ von Willebrand disease. Blood Coagul Fibrinol 2004, 15:503-504.

doi:10.1186/cc12581

Cite this article as: Repessé et al:: Recombinant factor VIla for uncontrollable bleeding in patients with extracorporeal membrane oxygenation: report on 15 cases and literature review. Critical Care 2013 $17: R 55$

Submit your next manuscript to BioMed Central and take full advantage of:

- Convenient online submission

- Thorough peer review

- No space constraints or color figure charges

- Immediate publication on acceptance

- Inclusion in PubMed, CAS, Scopus and Google Scholar

- Research which is freely available for redistribution

Submit your manuscript at www.biomedcentral.com/submit 